\title{
Impact of Emotional Needs on Intention to Stay and the Mediating Role of Perceived Organizational Support.an Empirical Study of Gen Y Employees' in the Banking Sector in Malaysia
}

\author{
Zabedah bt Othman, Dr Jugindar Singh Kartar Singh, Raemah Abdullah Hashim
}

\begin{abstract}
It is anticipated that over the next 10 years, the banking sector would require a workforce of about 200,000. Gen $Y$ employees makes up about $40 \%$ of the current workforce in Malaysia. This number is expected to increase to $75 \%$ within a relatively short span of time. The present study examined the influence of emotional needs of Gen Y employees towards intention to stay and the mediating role of perceived organizational support. This was a quantitative research that used a survey method. Data was collected from a sample of 470 Gen Y employees in the banking sector in Malaysia. The findings revealed that emotional needs had a significant impact on intention to stay. Perceived organizational support was found to mediate the relationship between the two. The findings have significantly contributed to the advancement of knowledge in the emotional needs and intention to stay of Gen Y employees in the banking sector. The significant and positive impact of emotional needs and perceived organizational support suggests the importance of these factors in retention of Gen $Y$ employees. The paper's primary contribution is that it provides an understanding that emotional needs and the mediating role of perceived organizational support have an impact on improving the intention to stay of Gen Y employees in the banking sector in Malaysia. From the practical implications perspective, organizations need to implement policies and procedures to help lessen employees quitting intentions. The results of this study suggest that organizations can implement policies covering the employee emotional needs and employees' perception that their work and contributions are valued. With current trends of globalizations and diversity, the finding of this study can be beneficial to improve retention of Gen $Y$ employees in other countries
\end{abstract}

Index Terms: Emotional needs, Perceived organizational support, Intention to stay, Gen Y, banking, emotions

\section{INTRODUCTION}

Malaysia's banking and financial services sector is going through a very dynamic phase and plays an essential role as a financial intermediary and is a primary source of financing for the domestic economy, accounting for about $70 \%$ of the

Revised Manuscript Received on September 22, 2019 idahothman88@gmail.com

Dr Jugindar Singh Kartar Singh, Asia Pacific University of Technology and Innovation, 57000 Kuala Lumpur,jugindar.singh@apu.edu.my

Raemah Abdullah Hashim, Open University of Malaysia, Email: raemah_abdullahhashim@oum.edu.my
Zabedah bt Othman, Open University of Malaysia,

total assets of the financial system at the end of 2015 (Bank Negara Malaysia, 2016). The financial performance of the banking system that comprises of 26 commercial banks and 16 Islamic banks was strong in the first half of 2018 (BNM, 2018). It is anticipated that over the next 10 years, the banking sector would require a workforce of about 200,000, an increase of 56,000 from the current 144,000 employees. (Star Online 2014). Many new jobs in the Malaysian banking sector are in the areas of automation and information technology (IT) (Star Online, 2018). There were over 4,000 vacancies in the banking industry. In addition, there were more than 4,500 new jobs created from January to November 2017 arising from digitalization. (Star Online, 2018).

Generation Y refers to individuals born from early 80 s through to the turn of the millennium (Strauss and Howe, 1991). At the moment Gen Y employees makes up about $40 \%$ of the current workforce in Malaysia. This number is expected to increase to $75 \%$ within a relatively short span of time. Within the next eight to nine years, it is expected that the Gen $\mathrm{Y}$ workforce in the banking system will rise to about $50 \%$ from $25 \%$ currently, which means that almost half of the people working in banks will be Gen Y employees, namely those below 30 years of age (Star Online, 2014). Attracting and retaining millennials is also a difficult challenge. Employees' intention to stay still remains as a key challenge to be achieved since Malaysia still struggles to the war on talent, as a result of a lack of sustainable employees' retention (Towers Watson, 2013). The Gen Y employees come to the job with a very different set of aspirations and are looking for work that inspires passion and allows them to fulfill their professional, personal, and social goals (Deloitte, 2014). Gen Y workers also look for instant gratification rather than long-term investments of effort and time (Southard and Lewis, 2004). Therefore, Gen Y employees will bring greater challenges for organizations if the organizations are not prepared to change their human resource policies (Guthridge, et al., 2008). This will lead to the talent crunch in the local financial services sector which is expected to worsen in the coming years partly driven by the Gen Y segment (Star Online, 2014). The talent shortage could be due to the lack of understanding on how to cope with the Gen Y group. Therefore, due to the expected rise of the Gen Y workforce in the financial services in the 
coming years, banks and other financial services sectors need to have a better understanding and knowledge of this group. In addition, retaining highly skilled employees, especially the Gen Y, is crucial due to business growth and the ability to attract and retain millennial talent will be a key step towards achieving the long term goals of organizations (PWC, 2012). Furthermore, millennials will be a powerful generation of how and where they work, and how they operate at the workplace (PWC, 2012). Thus, for organizational sustainability, it is imperative to effectively retain Gen Y employees and it is worth studying this phenomenon.

Based on past research, the intention to stay is related to various constructs. Queiri and Dwaikat (2016) identified constructs such as training, empowerment, organizational commitment, and lack of career planning. Choi et al. (2012) identified that emotional exhaustion, depersonalization, and reduced personal accomplishment increased turnover intentions. Study by Richman et al., (2008) revealed that perceived flexibility and supportive work-life policies were related to greater employee engagement and longer than expected retention. A study by PWC (2012) revealed that work life balance continues to be very important and work life balance is a priority for millennials. The report also stated that millennials value flexible working hours more that cash bonuses. Past studies have revealed that emotional needs are important to support employees against consequences of emotional labor, stress and exhaustion (Humphrey et al., 2015; Borhani et al. 2014). Past studies revealed that significant correlation was observed between the intensity and frequency of moral distress, professional stress, and intent to stay (Borhani et al., 2014). Acknowledgement of emotions and treating employees with respect leads to improvement in employees' engagement and intention to stay (Taris and Schreurs, 2009). Past studies have shown the relationship between emotions and perceived organizational support. A study by Hur, Won Moon and Jun (2013) showed that POS had a positive effect on the deep acting component of emotional labor. Perceived organizational support refers to feeling of being supported or valued by employers (Brown and Roloff, 2015). In a study by Schutte and Loi (2014), the mediation path models indicated that more satisfaction with social support in the workplace were linked to greater emotional intelligence. Therefore, higher emotional intelligence is associated with satisfaction with workplace support and this includes perception of employees concerning support (Schutte and Loi, 2014). Studies have revealed that perceived organizational support is closely linked to intention to stay and other positive outcomes in organizations (Liu and Liu, 2016). In several past studies, perceived organizational support, acted as a mediator between several human resource outcomes such as self-esteem (Liu and Liu, 2016) and emotional intelligence (Meisler and Vigoda-Gadot, (2014).

Retaining employees is also important as the cost of employee turnover is high and depending on the employee level, may average one and half times the employee's total annual compensation (Cappelli and Keller, 2013). Wilson (2012) stated that employee replacement costs can range between 90 to $100 \%$ of an employee's annual salary. Several studies were conducted on employees' turnover in organizations. However, the past studies focused mostly on intention to leave (Richman et al, 2008, Queiri and Dwaikat, 2016). There is limited research on Gen Y intention to stay in the banking sector in Malaysia. In addition, the influence of emotional needs towards intention to stay and the mediating role of perceived organizational support between the two has not empirically tested in the banking sector in Malaysia. There is also a dearth of research on the Gen Y employees' intention to stay in the banking sector in Malaysia. Furthermore, past studies have ignored the mediating role of perceived organizational support between emotional needs and intention to stay. Given the paucity of research in the Gen Y intention to stay, this paper adopts the position that there is a need to examine emotional needs that influence intention to stay and the mediating role of perceived organizational support. Findings of the study are expected to help human resource managers and policy-makers in the banking sector in Malaysia to design and implement more effective retention strategies for Gen Y employees.

\section{LITERATURE REVIEW}

\section{A. Intention To Stay}

There are several definitions of employees' turnover intention and intention to stay (Hewitt, 2004; Currivan, 2000). According to Hewitt (2004), intention to stay refers to and employee's willingness to remain employed in an organization and his/her level of commitment. Similarly, Currivan (2000) stated that intention to stay refers to the employees' tendency to stay or remain with their existing organization. Intention of employees to stay can be explained by the Theory of Planned Behavior, which explains that a person's intention to perform a specific behavior is the determinant of that behavior (Fishbein and Ajzen, 1980). The Social Exchange Theory (SET) by Thibaut and Kelley (1959), can also be used to explain the reasons why people have relationships with others. According to the Social Exchange Theory, good deeds need to be reciprocated (Blau, 1964). As stated by Cook et al., (2014), much of social life involves interactions between corporate actors and individual's groups, organizations or networks that can be viewed as social exchanges. The Social Exchange Theory enable actors to exercise power and influence and recent work also focuses on emotions and their role in social exchange (Cook et al., 2014). Jones (2011) tested hypotheses derived from organizational identification and social exchange theories and found that employees' attitude predicted outcomes such as intention to stay through its effect on organizational identification.

Based on past research, there are several reasons why employees remain with the current organization. There are also several impulsive factors that affect employee turnover (Guha and Chakrabarti, 2015). A study by Iftikhar et al. (2016) found that, psychological empowerment and citizenship behavior both had direct or indirect influence on turnover intentions of employees. Results of another study by Qureshi et al. (2013) revealed that job stress and workload were positively related to 
employee turnover intentions. Naim and Lenkla (2016) found that knowledge sharing in the organization has a great potential to generate a sense of affective commitment and intention to stay by Gen Y employees. Nasyira et al. (2014) found that perceived organizational support, perceived supervisor support and organization commitment were positively related with employee's intention to stay. Gupta and Singh (2018) stated that the perceived fairness in interpersonal treatment may impact employee's intention to stay more than the distribution of organizational rewards. Another study by Chen et al., (2016) found that social support, work stress and job satisfaction positively affected the intention to stay. Another study by Naim and Lenka (2017) revealed that mentoring of Gen Y employees had a direct influence on intention to stay. Results of another study by Othman and Lembang (2017) revealed that rewards and benefits, training and development, compensation and transformational leadership style influenced the Gen Y intention to stay. Based on the past research findings, several factors have been identified but there is a lack of research on the relationship between emotional needs and intention to stay of Gen Y employees.

\section{B. Relationship Between Emotional Needs And Intention To Stay}

Emotional needs refer a psychological or mental requirement of intrapsychic origin that usually centers on such basic feelings as love, fear, anger, sorrow, anxiety, frustration, and depression and involves the understanding, empathy, and support of one person for another (Mosby's Medical Dictionary, 2018). Mayer et al., (2004) stated that emotional needs are direct responses to events, issues, relationships and objects that are essential to individuals. Falkenburg and Schyns (2007) asserted that emotional needs play an extensive role in thought processes. Ashkanasy and Daus (2002) undertook a study of emotions in organizational settings and concluded that emotions provided new and important insights into the way in which employees in organizations behave. Therefore, as stated by Ashkanasy and Daus (2002), managers should develop and to maintain a positive emotional climate in their organizations. The main distinction of the emotional needs according to Wong and Law (2002) lies on the ability to determine and express one's own emotions, to use emotions to aid the cognitive processes, managing their emotional process and lastly to control his/her immediate reactions. Past studies have established that emotion is central to all aspects of the human experience since all individuals use their emotional needs effectively in problem solving and reasoning in an organization (Stanley and Burrows, 2001). Past research have established that emotional needs are essential towards significantly improving individual, team and organizational effectiveness in various fields such as: decision-making (Mele, 2001) and coping with environmental stressors (Zeidner, Matthews and Roberts, 2004). However, emotional needs can be disruptive or dangerous or it can push a person towards an illogical course of action or help an individual make quick and useful decisions in the workplace (Woolfolk, 2004).
Past research has revealed that emotional needs are related to health and employees' intention to stay. Emotional needs are related to emotional demands and previous researchers have stated that emotional demands are a very important aspect of health outcomes (Worley et al., 2008). According to World Health Organization (2008), emotional demands at work can take place when the employee has some degree of control in relation to the person that the employee is responsible for serving. Van Vegchel et al. (2004) stated that the definition of emotional demands at work refer to the aspects of the employee job that require sustained emotional effort due to the interactional contact with customers and clients. Research have found that when emotions were acknowledged and treated with respect, the employees' engagement improved (Smollan and Sayers, 2009; Taris and Schreurs, 2009). A study by Taris et al. (2009) revealed that there was a relationship between emotional demands and exhaustion. Related to emotional needs is emotional labor and Hochschild (1983) defined emotional labor as a form of emotional regulation, or, the management of feeling to create a publicly observable facial and bodily display. Hochschild (1983) proposed that emotional labor causes burnout and job stress and therefore was potentially damaging to employees' mental health and this could affect their intention to stay. On the contrary, Humphrey et al. (2015) found that emotional labor may also have positive outcomes when organizations adopt positive display rules that call for the expression of positive emotions by employees such as front line staff. However, Liang et al. (2016) found that intention to stay was positively related with age and the safety climate but emotional labor was not positively related. Based on a study by Borhani et al. (2014), it was revealed that significant correlation was observed between the intensity and frequency of moral distress, professional stress, and intent to stay. The study by Borhani et al. (2014) also revealed that there was a significant correlation between moral distress, professional stress and number of years in work setting. Cummings (2009) also concluded that that high levels of moral distress and professional stress are associated with employees leaving the profession. Based on the past research findings discussed above and logically extending them, the following hypothesis was formulated for testing in the present study.

H1. Emotional needs are related to Gen Y employees' intention to stay in the banking sector in Malaysia.

\section{The mediating role of Perceived Organizational support (POS)}

According to Brown and Roloff (2015), employees are empowered with perceived organizational support (POS) when they perceive themselves and their work contributions as valued, cared and supported by their employers. According to Aube, Rousseau and Morin (2007), POS is the degree to which employees perceived that the organization is willing to fairly compensate them with the exchange of their performance, assist them to make their job more interesting and challenging, and provide them with safe working environment. Researchers

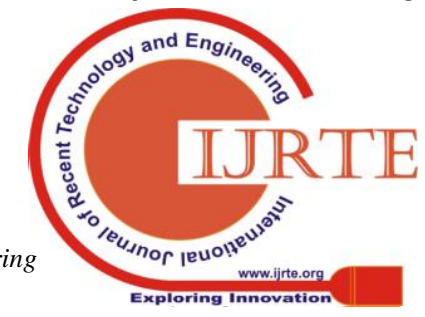


have recognized that higher levels of POS are linked to better performance, job satisfaction and well-being, and lower levels with burnout and intentions to quit (Brown and Roloff, 2015). Eisenberger and Stinglhamber (2011) used the organizational support theory and evidence gathered from hundreds of studies to show that POS affects employees' well-being and behavioral outcomes favorable to the organization. According to Kurtessis et al. (2017), the organizational support theory (OST) proposes that employees form a generalized perception concerning the extent to which the organization values their contributions and cares about their well-being. The findings of a study by Eisenberger and Stinglhamber (2011) were consistent with organizational support theory's assumption that POS strengthens affective commitment and performance by a reciprocation process. Therefore, the perception of the organization commitment to employees will increase their commitment to the organization.

Ramlall (2003) mentioned that people strive to work and to stay in corporations that provided positive work environments where employees felt they are valued. A positive valuation by the organization also provides an indication that increased effort and productivity will be highly recognized and rewarded by the organization (Eisenberger and Stinglhamber, 2011). Colakoglu (2010) further stated that organizational support is of great importance for employees and one of the main factor to enhance their job satisfaction and organizational commitment. The results of another study by Cho et al. (2009) revealed that perceived organizational support and organizational commitment decreased intent to leave while only perceived organizational support had a positive impact on intention to stay (Cho et al., 2009). Another study by Lamm et al. (2015) found that POS was positively related to job satisfaction, organizational identification, and psychological empowerment, and negatively related to turnover intentions. Thus, when employees realize that organizations supported them, they will perform their best and will remain employed in the organization for a longer time.

Past research has shown that emotional demands and burnout decreases job performance (e.g., Tubre \& Collins, 2000) and increases intentions to quit (Cropanzano, Rupp, \& Byrne, 2003). To fulfill the emotional needs, researchers stated that organizations need to increase the caring, respect, and approval associated with perceived organizational support (Laschinger, et al., 2006). A greater amount of perceived organizational support provides assistance to employees in terms of socioemotional needs and other assistance (Hochwarter et al., 2006). Past research found that perceived organizational support was associated with less emotional exhaustion and depersonalization and moderated the role conflict-emotional exhaustion relationship (Jawahar et al., 2007). The results of a study by Hur et al. (2015) showed that POS had a positive effect on emotional labor and emotional exhaustion had a negative relationship with organizational commitment, while organizational commitment had a negative relationship on turnover intention. The study by Kumar Mishra (2014) further found that POS was positively related to deep acting and negatively related to surface acting. Based on past research, higher POS will increase the employees' commitment and motivation and lower the employees' intention to quit from the organization. Therefore, as stated by Eisenberger and Stinglhamber (2011), employees with high POS will show higher commitment and lower intention to leave.

In this study it is hypothesized that perceived organizational support mediates the effects of emotional needs on intention to stay. Based on past research, perceived organizations support has been used as a mediator between various human resource constructs and practices (Iftikhar et al., 2015; Cheung, 2013; Allen et al., 2003). A study by Iftikhar et al. (2016) found that affective commitment acted as a mediating variable between organizational citizenship behavior and turnover intentions as well as psychological empowerment and turnover intention of employees. Results of a study Cheung (2013) found that perceived organizational support mediated the effects of informational and interpersonal justice on organizational citizenship behavior. Another study by Meisler and Vigoda-Gadot, (2014) found that perceived organizational politics mediated the relationship between emotional intelligence and turnover intentions. Results of a study by Cullen et al., (2014) found support for the role of perceived organizational support as a mediator of the relationship between employees' adaptability and perceptions of change-related uncertainty and employees' satisfaction and performance. The study by Allen et al. (2003) found that perceived organizational support mediated their relationships with organizational commitment and job satisfaction. Past research has indicated that there is a relationship between POS and both emotional needs and intention to stay. Based on the pattern of relationships and the role of POS as a mediator between several other human resource practices, it is believed that the relationship of emotional needs and intention to stay is mediated by POS. Based on the argument, it is hypothesized that:

$\mathrm{H} 2$ : Perceived organizational support mediates the relationship between emotional needs and Gen Y intention to stay.

\section{METHODOLOGY AND RESEARCH DESIGN}

\section{A. Research Design}

This study used a quantitative approach to collect primary data. The research strategy is to find out the causal relationship among variables (Sekaran and Bougie, 2016). A deductive approach and a survey strategy was chosen because it allows the researcher to collect quantitative data on the research questions of this study (Sekaran and Bougie, 2016). The focus was to use self-administered questionnaires to collect numerical data from Gen $\mathrm{Y}$ employees in the banking sector. This was a cross-sectional study where

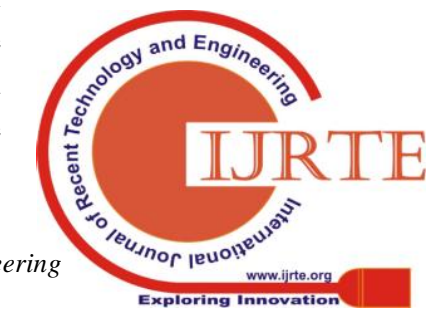


data was collected only once representing a snapshot of one point in time (Sekaran and Bougie, 2016). The researcher used SPSS and Smart-PLS to analyze the data.

\section{B. Sampling Technique and Sample Size}

The population refers to the entire group of people for which the researcher wants to make inferences (Sekaran and Bougie, 2016). The population for this study were Gen Y employees engaged in the banking sector. A sample is a subset of the population and a sampling frame was drawn. Probability sampling design known as simple random sampling where every element in the population had a known and equal chance of being selected as a subject was used (Sekaran and Bougie, 2016). For this study, a total of 200 names were chosen from each of the five major banks in Kuala Lumpur, to create a sampling frame of a total of 1,000 names. These names were written on individual pieces of paper and were placed in a box where a total of 500 names were randomly picked from the box. Based on an estimated population of 100,000 Gen Y employees, the sample size calculated according to the formula by Krejcie and Morgan (1970) was 384 respondents. Hair et al. (2010) suggests that the minimum sample size is 100 when considering models containing five or fewer constructs, each with more than three items; 150 when models contain seven or fewer constructs. It is generally regarded that 100 is the practical minimum size for using Structural Equation Modelling (SEM) (Hair et al., 2010).

\section{Instrumentation}

For this study, the questionnaire consists of 4 parts. The first part was designed for the demographic information of the employees. The questions used in this questionnaire were adapted from past research. The second part were closed ended questions on the dependant variable. The Likert five-point-scale questions on intention to stay were adapted from Kyndt et al. (2009). The third part were closed ended questions on the independent variable. The questions on emotional needs were adapted from the 16-item emotional intelligence scale developed by Wong and Law (2002). The last part was questions to measure the mediating role of perceived organizational support. The Likert five-point-scale questions for perceived organisational support was adapted from Rhoades and Eisenberger (2001). The fixed alternative questions required the respondents to choose the best answer based on a five- point Likert-type scale. The pilot study using 30 respondents was used to test the instrument. The purpose of the pilot was to refine the questionnaire (Saunders et al., 2012). Based on the pilot testing, ambiguous, unclear and confusing questions were reviewed and rectified accordingly. Based on reliability testing, none of the questions was deleted. There were minor changes to four questions to improve the understanding of questionnaire. In this study, grammar and typing mistakes were rectified for 5 questions. The question number 8 on social needs was reworded for better understanding.

\section{Data Collection}

The questionnaires were personally sent to the respondents whose names had been picked by using the "drop and collect" method. Approval was obtained and meetings were arranged with the Human Resource managers and top management from the selected banks. The direct distribute and collect method was used because of the faster speed in getting responses and respondents that could be reached personally. A cover letter stating the purpose of the survey was sent together with the questionnaire, follow-up calls were made to the respondents and two weeks were given for the employees to fill up the questionnaire. The response rate was very encouraging and higher than expected with 470 respondents or $94 \%$ returning the questionnaire.

\section{E. Data Analyses}

After the data was collected through questionnaires, it was coded, keyed in, and edited. Preliminary checking was done and the outliers, inconsistencies, and blank responses were handled. Feel of data was acquired by obtaining a visual summary and by checking the central tendency and the dispersion of a variables. The Package for Social Sciences (SPSS) version 22 and Smart Partial Least Square (PLS) Version 2.0 were used. The reliability and validity of the measures was tested. Subsequently, the hypothesized relationship was tested and the purpose of hypothesis testing was to determine accurately if the null hypothesis can be rejected in favour of the alternate hypothesis (Sekaran and Bougie, 2016). Bootstrapping method (1,000 resamples) was used to determine the significance levels for loadings, weights and path coefficients.

\section{RESULTS}

\section{A. Demographic profiles of the respondents}

The respondents included $49 \%(\mathrm{n}=230)$ female and $51 \%$ $(n=240)$ male. Majority of the respondents, 68\% $(n=324)$ were single. The respondents age included $31 \%$ between the age range of 19 to 24 years, $51 \%$ between the age range of 25 to 30 years, $18 \%$ above the age range of 30 years. In terms of qualification, there 14 postgraduates, 223 were degree holders and 233 people had either a Diploma/Certificate or lower qualification. For length of employment, $37 \%$ were worked for less than a year, $23 \%$, worked for 1 to 2 years and $12 \%$ of respondents have worked in the company for 2 to 3 years.

\section{B. Descriptive Statistics}

Table 1 shows the values for skewness is between the ranges of .028 to .055 and the values for kurtosis are between the ranges of -.083 to -.22 . Therefore, the values of skewness and kurtosis values are within +1 and -1 standard deviations from its mean (Hair et al., 2010). The mean of all the variables is above 3.7 and the standard deviation is low. The multi-collinearity results are presented in the Table 1 and the two values are Tolerance and VIF. A common cut-off threshold is a tolerance value of .10, which corresponds to a VIF value of 10 (Hair et al., 2010). As shown in Table 1 , the value of tolerance is not less than .10; therefore, the

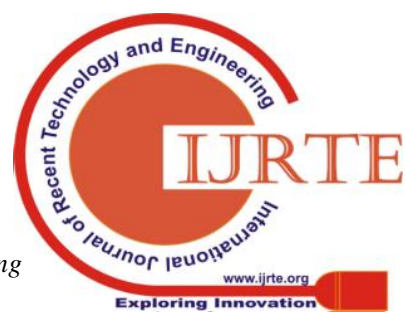


multicollinearity assumption is not violated. This is further supported by the VIF values which fall below the cut-off of 10 .

TABLE 1: DESCRIPTIVE STATISTICS

\begin{tabular}{|l|c|c|c|c|c|c|}
\hline & $\begin{array}{c}\text { Mea } \\
\mathrm{n}\end{array}$ & $\begin{array}{c}\text { Std. } \\
\text { Deviati } \\
\text { on }\end{array}$ & $\begin{array}{c}\text { Skewne } \\
\text { ss }\end{array}$ & $\begin{array}{c}\text { Kurtos } \\
\text { is }\end{array}$ & $\begin{array}{c}\text { Toleran } \\
\text { ce }\end{array}$ & $\begin{array}{c}\text { VI } \\
\mathrm{F}\end{array}$ \\
\hline $\begin{array}{l}\text { Emotional } \\
\text { Needs }\end{array}$ & $\begin{array}{c}3.98 \\
0\end{array}$ & 0.41 & 0.286 & -0.083 & 0.49 & $\begin{array}{c}2.0 \\
4\end{array}$ \\
\hline POS & $\begin{array}{c}3.69 \\
6\end{array}$ & 0.56 & 0.185 & -0.22 & 0.52 & $\begin{array}{c}1.9 \\
2\end{array}$ \\
\hline $\begin{array}{l}\text { Intention to } \\
\text { Stay }\end{array}$ & $\begin{array}{c}3.70 \\
4\end{array}$ & 0.62 & 0.058 & -0.193 & & \\
\hline
\end{tabular}

\section{Reliability}

Reliability is the extent to which it is without bias and hence ensures consistent measurement across time and across various items in the instrument (Sekaran and Bougie, 2010). According to Sekaran \& Bougie (2010), a reliability value of less than 0.6 is considered as poor, a reliability value 0.7 is considered acceptable, and reliability a value of 0.8 is considered as good. The closer the score is to 1.0 the better. Based on Table 2, the result showed that the rho values for each construct are above 0.80 and below 0.947 . For a good reliability, the reliability coefficient or Cronbach's alpha should be .7 or higher (Hair et al., 2010). Based on Table 2, all the constructs Cronbach's Alpha values were higher than 0.7 .

TABLE 2: ConStruCt VALIDITY RELIABILITY

\begin{tabular}{|l|l|l|l|l|}
\hline & $\begin{array}{l}\text { Cronbach } \\
\text { 's } \\
\text { Alpha }\end{array}$ & rho_A & $\begin{array}{l}\text { Composi } \\
\text { te } \\
\text { Reliabili } \\
\text { ty }\end{array}$ & $\begin{array}{l}\text { Average } \\
\text { Variance } \\
\text { Extracted } \\
\text { (AVE) }\end{array}$ \\
\hline $\begin{array}{l}\text { Emotional } \\
\text { Needs }\end{array}$ & 0.811 & 0.822 & 0.864 & 0.516 \\
\hline $\begin{array}{l}\text { Intention to } \\
\text { Leave }\end{array}$ & 0.917 & 0.922 & 0.931 & 0.575 \\
\hline $\begin{array}{l}\text { Perceived Org } \\
\text { Support }\end{array}$ & 0.945 & 0.947 & 0.951 & 0.566 \\
\hline
\end{tabular}

\section{Convergent Validity and Coefficient of Determination (R2)}

Convergent validity used to measure and examine the extent that a construct converges the specific construct's indicators by explaining the items' variance (Hair et al., 2010). The mean of the squared loadings for all indicators associated with the construct is the calculation method to calculate the value of AVE (Sarstedt, et al. (2014). The minimum acceptable value for AVE is 0.5 and if the value is more than 0.5, the result represented that the construct explains more than $50 \%$ of the variance of items. Based on Table 2, all the AVE values for the constructs exceeded 0.5 and therefore, the convergent validity was established in this research. Loadings less than the suggested value were deleted. As shown in Figure 1, the loadings for all the items, exceed the threshold value of 0.6 (Hair et al., 2010). The coefficient of determination (R2) value represents the combined effects of the independent variables on dependent variables. The $\mathrm{R} 2$ value for the overall model here is moderate (52\%). 4.4 Discriminant Validity
According to Hair, et al. (2010), discriminant validity is used to measure the different constructs differ from one another, in terms of how much a variable correlate with other variables and how much the indicators represent only a single variable. Fornell-Larcker criterion that focus on the comparison of each construct's AVE value with the square root of inter-construct correlation was used (Sarstedt, et al., 2014). According to Hair, et al. (2010) and Sarstedt, et al. (2014), if the indicator's loadings are consistently the highest for the construct, then the discriminant validity is established. Based on the table 3, the results show that all the indicator's loadings were consistently the highest on each of the constructs. Therefore, the results showed that the discriminant validity was valid and represented that the measurement model has been validated.

TABLE 3: DISCRIMINANT VALIDITY

\begin{tabular}{|l|c|c|c|}
\hline & $\begin{array}{l}\text { Emotional } \\
\text { Needs }\end{array}$ & $\begin{array}{l}\text { Intention to } \\
\text { leave }\end{array}$ & $\begin{array}{l}\text { Perceived } \\
\text { orgn Support }\end{array}$ \\
\hline Emotional Needs & 0.718 & & \\
\hline Intention to Leave & 0.394 & 0.759 & 0.752 \\
\hline $\begin{array}{l}\text { Perceived Org } \\
\text { Support }\end{array}$ & 0.386 & 0.707 & \\
\hline
\end{tabular}

\section{E. Significance and Relevance of Path Coefficients}

In Table 4, the t-value was examined and a value that is greater than 1.96 represents a significant path (Hair et al., 2010). For emotional needs, the t-value is significant. In Table 4, the path coefficient shows the strength of relationship between an IV and DV (Hair et al., 2010). The standardized regression value of .142 shows a positive relationship between emotional needs and intention to stay and the effect is insignificant ( $p>0.05)$. Thus, the hypothesis $\mathrm{H} 1$ is supported. In this study, bootstrapping was done without the interaction of a mediator. The results reveal that both direct paths were statistically significant. Based on the $t$ value of the indirect path, with a $p$ value that is significant, it can be concluded that perceived organizational support mediates the relationship between emotional needs and intention to stay.

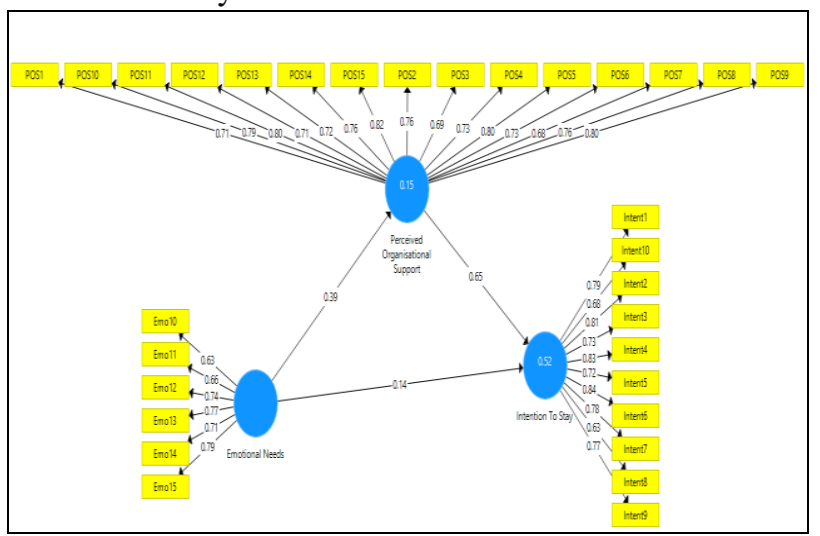

Fig 1: Path Coefficients diagram

\section{Table 4: Path Coefficients}




\begin{tabular}{|l|l|l|l|l|}
\hline & $\begin{array}{l}\text { Path } \\
\text { Coeff }\end{array}$ & $\begin{array}{l}\text { Standar } \\
\mathrm{d} \\
\text { Deviati } \\
\text { on }\end{array}$ & $\begin{array}{l}\text { T } \\
\text { Statisti } \\
\text { cs }\end{array}$ & $\begin{array}{l}\text { V } \\
\text { Value }\end{array}$ \\
\hline $\begin{array}{l}\text { Emotional Needs -> } \\
\text { Intention To Stay }\end{array}$ & 0.142 & 0.038 & 3.714 & 0 \\
\hline $\begin{array}{l}\text { Emotional Needs -> } \\
\text { Perceived Orgn Support }\end{array}$ & 0.389 & 0.043 & 8.992 & 0 \\
\hline $\begin{array}{l}\text { Perceived Orgn. Support } \\
->\text { Intention To Stay }\end{array}$ & 0.654 & 0.028 & 23.129 & 0 \\
\hline
\end{tabular}

\section{DISCUSSION AND CONCLUSION}

The aim of this study was to provide a broader understanding of the influence of emotional needs towards intention to stay and the mediating role of perceived organizational support. In this study, emotional needs were hypothesized to influence intention to stay by Gen Y employees in the banking sector. The results of this study supported the hypothesis $(\beta 1=.142, \mathrm{p}<0.001)$. An increase in emotional needs will result in a higher increase in the intention to stay of Gen Y employees. This is consistent with past studies that have established that emotion is central to all aspects of the human experience since all individuals use their emotional needs effectively in problem solving and reasoning in an organization (Falkenburg and Schyns, 2007; Borhani et al., 2014). Past research have shown that high levels of moral distress and professional stress are associated with employees leaving the profession (Cummings, 2009). Therefore, as stated by Ashkanasy and Daus (2002), organizations should provide an emotionally healthy workplace atmosphere where emotional challenges of the job are recognized, discussed, and managed. Organizations should implement strategies that are truly supporting emotional needs and Gen Y employees' intention to stay longer with organizations.

An interesting finding that emerged was the mediating role of perceived organizational support. It was hypothesized that perceived organizational support mediates the effects of emotional needs on Gen Y intention to stay. In this study, it was examined how POS influences Gen Y intention to stay both directly and indirectly. In this study, POS was found to mediate the relationship between emotional needs and intention to stay. This means the variance in intention to stay is attributable to emotional needs is partly a direct effect, and partly an indirect effect mediated through POS. In this study it can be concluded that in addition to the direct effect, emotional needs predict POS and POS in turn predicts intention to stay among Gen Y employees in the banking sector in Malaysia. The results of the study are generally congruent with the findings of studies examining the mediating effect of several human resource practices (Meisler and Vigoda-Gadot, 2014; Cullen et al. 2014). The interrelationships among emotional needs, POS and intention to stay suggest that both the emotional needs and POS are important in increasing Gen Y intention to stay.

Theoretically in the domain of employee intention to stay, this study provide several implications for organizations and Gen Y employees intention to stay in the banking sector in Malaysia. The results from this study provided new knowledge by understanding the personal needs of the Gen Y in the Malaysian banking sector, with regards to the emotional needs of the employees. The findings will also provide theoretical, policy and practical implications for policymakers, organizations and institutions to support Gen $\mathrm{Y}$ employees with the intention to stay. From a theoretical standpoint, this study helps to fill the research gaps by providing new information towards retention of Gen $\mathrm{Y}$ employees. It was clear from the literature review that one of the major gaps was the paucity of research relating to the relationship between the Gen Y's emotional needs and their intention to stay. Accordingly, this study enhanced the Gen Y research and the findings of this study contributed to the body of knowledge. As such, the results are expected to aid in formation of foundation solutions to assist the retention of Gen Y employees engaged by organizations in the banking sector in Malaysia. From a practical standpoint, organizations and policy makers gain the understanding of factors to retain Gen Y employees for longer period. The results this study suggest that organizations should understand the emotional needs that drives Gen Y employees and what are the factors that affect their decision to remain as an employee with the organization. The inclusion of mediator variable of perceived organizational support further strengthened the framework to be more unique and more comprehensive. From the policy implications perspective, organizations can use the results of this study to design specific employee retention policies aimed to encourage employees to stay longer. In the banking sector, organizations can develop and implement policies covering the employee emotional needs which can increase their intention to stay. Therefore, human resource practitioners in the in the banking sector should focus on developing employee support policies and practices and create a supportive working environment. Organizations should also take measures to implement internal policies to support and provide meaningful work to Gen Y employees. Thus, from the results, organisations should emphasise more towards creating a working environment advantageous to the Gen Y employee's needs. Organisations could implement or update preceding practices or policies to accommodate specifically the emotional needs of the Gen Y employees to enrich their intention to stay. This study made an important contribution to understanding the influence of emotional needs of generation $\mathrm{Y}$ employees towards intention to stay and the mediating role of perceived organizational support. However, it was not possible to examine employee populations across different countries and industries. Therefore, the generalizability of the findings of this research in other countries and contexts should be tested further through replication studies in other countries.

Despite the significant findings of this study, there are some limitations. Accordingly, these issues and the limitations of the study will provide strong directions towards future research. These limitations open several recommendations for future research. This study concentrated only on emotional needs of Gen Y employees. For future research, other human needs such as social needs, safety needs, security needs, physiological needs or self-actualisation needs could also be explored further. This research focussed only on the banking sector and future

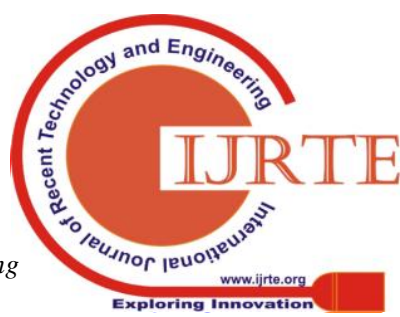




\section{Impact of Emotional Needs on Intention to Stay and the Mediating Role of Perceived Organizational Support.an Empirical Study of Gen Y Employees' in the Banking Sector in Malaysia}

research should replicate the framework of this study in other settings, or within other service sectors such as hotels, insurance, food services and hospitality. Future studies could also use a mixed method approach which can be either an explanatory sequential approach or an exploratory sequential approach for more in-depth results. The future study can be based on two sources of data from employees and management staff. This could be a better measure of the employees' perceptions towards intention to stay and employee retention. In addition, future studies could also consider other alternative methods for data collection such as experiments, observations or doing interviews to understand the employees' intention to stay. The sample size was also small and may not be sufficient to generalize the results. Future studies should look at bigger samples to improve the results.

\section{REFERENCES}

1. Ajzen, I. \& Fishbein, M. (1980). Understanding attitudes and predicting social behavior. Englewood Cliffs,

2. NJ: Prentice Hall.

3. Allen, D.G., Shore, L.M. and Griffeth, R.W. (2003). The role of perceived organizational support and

4. supportive human resource practices in the turnover process. Journal of management, 29(1), 99-118.

5. Ashkanasy, N.M. and Daus, C.S. (2002). Emotion in the workplace: The new challenge for managers.

6. Academy of Management Perspectives, 16(1), 76-86.

7. Aube, C., Rousseau, V. \& Morin, M.E. (2007). Perceived organizational support and organizational commitment: The moderating effect of locus of control and work autonomy. Journal of Managerial Psychology, 22(5), 479-495

8. Burmeister, M. (2009). It's all about me becomes a cross generational conversation. Training and

9. Development, 63(5), 92-93

10. Blau, P.M. (1964). Exchange and power in social life. New York: John Wiley and Sons.

11. BNM, (2016). Bank Negara Malaysia Report [Online]. Available at http://www.bnm.gov.my/

12. (Accessed Sept 5, 2018)

13. BNM, (2018). Bank Negara Malaysia Financial Stability Review - First Half 2018 [Online]. Available at

14. http://www.bnm.gov.my/index.php?ch=en_press\&pg=en_ (Accessed Sept 5, 2018)

15. Borhani, F., Abbaszadeh, A., Nakhaee, N. and Roshanzadeh, M. (2014). The relationship between moral

16. distress, professional stress, and intent to stay in the nursing profession. Journal of medical ethics and history of medicine, 7(4), 1-8

17. Brown, L.A. and Roloff, M.E. (2015). Perceived Organizational Support. The International Encyclopedia

18. of Interpersonal Communication. New York: John Wiley \& Sons

19. Cappelli, P., \& Keller, J. R. (2013). Classifying work in the new economy. Academy of Management Review,

20. 38(4), 575-596

21. Chen, M.F., Ho, C.H., Lin, C.F., Chung, M.H., Chao, W.C., Chou, H.L. and Li, C.K. (2016). Organization-

22. based self-esteem mediates the effects of social support and job satisfaction on intention to stay in nurses. Journal of nursing management, 24(1), 88-96.

23. Cheung, M.F. (2013). The mediating role of perceived organizational support in the effects of interpersonal

24. and informational justice on organizational citizenship behaviors. Leadership \& Organization Development Journal, 34(6), 551-572.

25. Cho, S., Johanson, M.M. and Guchait, P. (2009). Employees intent to leave: A comparison of determinants

26. of intent to leave versus intent to stay. International Journal of Hospitality Management, 28(3), 374-381.

27. Choi, S., Cheong, K. and Feinberg, R.A. (2012). Moderating effects of supervisor support, monetary

28. rewards, and career paths on the relationship between job burnout and turnover intentions in the context of call centers. Managing Service Quality: An International Journal, 22(5), 492-516.
29. Colakoglu, U., Culha, O., \& Atay, H. (2010). The effects of perceived organizational support on employee's

30. affective outcome: Evidence from Hotel Industry. Tourism and Hospitality Management, 16(2), 125-150.

31. Cook, K.S., Cheshire, C., Rice, E.R. and Nakagawa, S. (2013). Social exchange theory. In Handbook of

32. social psychology (pp. 61-88). Springer, Dordrecht.

33. Cropanzano, R., Rupp, D. E., \& Byrne, Z. S. (2003). The relationship of emotional exhaustion to work

34. attitudes, job performance and organizational citizenship behaviors Journal of Applied Psychology, 88, 160 -169.

35. Cullen, K.L., Edwards, B.D., Casper, W.C. and Gue, K.R. (2014) Employees' adaptability and perceptions

36. of change-related uncertainty: Implications for perceived organizational support, job satisfaction, and performance. Journal of Business and Psychology, 29(2), 269-280.

37. Currivan, D.B. (2000). The causal order of job satisfaction and organizational commitment in models of

38. employee turnover, Human Resource Management Review, 9(4), 495-524

39. Cummings CL. (2009). The effect of moral distress on nursing retention in the acute care setting

40. [unpublished dissertation] Florida (USA): University of North Florida

41. Deloitte, (2014). Big demands and high expectations: The Deloitte Millennial survey, (Online).

42. Available at http://www2.deloitte.com/content/dam/Deloitte/global/ (Assessed July 19, 2018)

43. Eisenberger, R. and Stinglhamber, F. (2011). Perceived organizational support: Fostering enthusiastic

44. and productive employees. American Psychological Association.

45. Falkenburg, K \& Schyns, B. (2007). Work satisfaction, organizational commitment and withdrawal

46. behaviours. Management Research News, 30(10), 708-723. (Online). Available at:

47. http://www.emeraldinsight.com/ [Accessed February 16, 2018]

48. Gupta, A. and Singh, V. (2018). Influence of organizational justice on intention to stay of IT

49. professionals. International Journal of Indian Culture and Business Management, 17(4), 428-441

50. Guthridge, M., Komm, A.B., \& Lawson, E. (2008). Making talent a strategic priority. The McKinsey

51. Quaterly, 1- 59

52. Hewitt Associates. (2004). Strategies for Cost Management of the HR Function. Timely Topics Survey

53. Results.

54. Hochschild, A. R. (1983). The managed heart: Commercialization of human feeling. Berkeley: University of

55. California Press.

56. Hochwarter, W.A., L.A. Witt, D.C. Treadway, \& G.R. Ferris (2006). The interaction of social skill and

57. organizational support on job performance. Journal of Applied Psychology, 91(2): 482-489.

58. Guha, S. and Chakrabarti, S. (2015). Effects of Intrinsic and Extrinsic Factors on Voluntary Employee

59. Turnover: An Alternative Exposition. Anvesha, 8(3), 1-17

60. Hair, J. F., Black, W.C., Babin, J.B., Anderson, R.E., \& Tatham, R.L. (2010). Multivariate Data

61. Analysis. Pearson Prentice-Hall International, Upper Saddle River, New Jersey, U.S.A.

62. Humphrey, R.H., Ashforth, B.E. and Diefendorff, J.M., 2015. The bright side of emotional labor. Journal of

63. Organizational Behavior, 36(6), 749-769

64. Hur, W.M., Han, S.J., Yoo, J.J. and Moon, T.W. (2015). The moderating role of perceived organizational

65. support on the relationship between emotional labor and job-related outcomes. Management Decision, 53(3), 605-624.

66. Hur, W.M., Won Moon, T. and Jun, J.K. (2013). The role of perceived organizational support on emotional

67. labor in the airline industry. International Journal of Contemporary Hospitality Management, 25(1), pp.105-123.

68. Iftikhar, M., Shahid, M.U., Shahab, M.H., Mobeen, M. and Qureshi, M.I (2016). Exploring the relationship

69. among organizational citizenship behavior, psychological empowerment and turnover intensions with the mediating role of affective commitment. International Review of Management and Marketing, 6(4S), pp.296-304.

70. Jawahar, I.M., Stone, T.H. and Kisamore, J.L. (2007). Role conflict and burnout: The direct and moderating

71. effects of political skill and perceived organizational support on burnout dimensions.

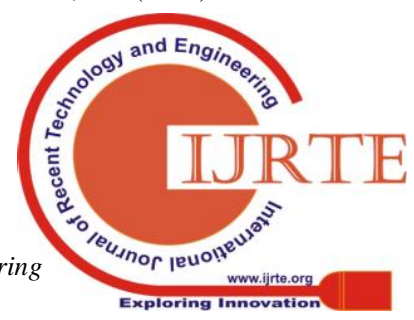


International Journal of Stress Management, 14(2), 142-159.

72. Jones, D.A. (2010). Does serving the community also serve the company? Using organizational

73. identification and social exchange theories to understand employee responses to a volunteerism programme. Journal of Occupational and Organizational Psychology, 83(4), 857-878.

74. Krejcie, R. V. and Morgan, D. W. (1970). Determining sample size for research activities.

75. Educational and Psychological Measurement, 30, 607-610.

76. Kurtessis, J.N., Eisenberger, R., Ford, M.T., Buffardi, L.C., Stewart, K.A. and Adis, C.S. (2017).

77. Perceived organizational support: A meta-analytic evaluation of organizational support theory. Journal of Management, 43(6), 854-1884.

78. Kumar Mishra, S. (2014). Linking perceived organizational support to emotional labor. Personnel

79. Review, 43(6), 845-860.

80. Kyndt, E. Dochy, F. Michielsen, M. \& Moeyaert, B. (2009). Employee retention: Organizational and personal perspectives. Vocations and Learning, 2(3), 195-215.

81. Lamm, E., Tosti-Kharas, J. and King, C.E. (2015). Empowering employee sustainability: Perceived

82. organizational support toward the environment. Journal of Business Ethics, 128(1), 207-220.

83. Laschinger, H.K.S., N. Purdy, J. Cho, \& J. Almost, 2006. Antecedents and consequences of nurse managers

84. perceptions of organizational support. Nursing Economics, 24(1), 20-29

85. Liang, H.Y., Tang, F.I., Wang, T.F., Lin, K.C. and Yu, S., 2016. Nurse characteristics, leadership, safety

86. climate, emotional labor and intention to stay for nurses: a structura equation modelling approach. Journal of advanced nursing, 72(12), 3068-3080.

87. Liu, J. and Liu, Y.H. (2016). Perceived organizational support and intention to remain: The mediating

88. roles of career success and self-esteem. Int. journal of nursing practice, 22(2), pp.205-214.Mayer, J.D., Salovey, P., \& Caruso, D.R. (2004). Emotional intelligence: Theory, findings, and

89. implications. Psychological Inquiry, 15, 197-215.

90. Meisler, G. and Vigoda-Gadot, E. (2014). Perceived organizational politics, emotional intelligence and

91. work outcomes: empirical exploration of direct and indirect effects. Personnel Review, 43(1), 116-135.

92. Mele, A. R. (2001). Self-Deception Unmasked. Princeton: Princeton University Press

93. Mosby's Medical Dictionary, 8th edition. (2009). (Online). Available at https://medical-

94. dictionary.thefreedictionary.com/emotional need_Accessed August 5, $\underline{2018)}$

95. Naim, M.F. and Lenkla, U. (2016). Knowledge sharing as an intervention for Gen Y employees' intention

96. to stay. Industrial and Commercial Training, 48(3), 142-148.

97. Nasyira, M.N., Othman, M. and Ghazali, H. (2014). Predictors of intention to stay for employees of

98. casual dining restaurant in Klang Valley area. International Food Research Journal, 21(3).

99. Naim, M.F. and Lenka, U. (2017). How does mentoring contribute to Gen $\mathrm{Y}$ employees' intention to

100. stay? An Indian perspective. Europe's journal of psychology, 13(2), 314

101. Othman, S.Z. and Lembang, S.A. (2017). What Attract Gen Y to Stay in Organization? HR Practices,

102. Organizational Support or Leadership Style. International Review of Management and Marketing, 7(2), 1-9.

103. PWC, (2012). Millennials at work Reshaping the workforce. (Online) Available at

104. https://www.pwc.com/my/en/assets/publications/millennials (Assessed January 12,2018 )

105. Queiri, A. and Dwaikat, N. (2016). Factors affecting generation Y employees' intention to quit in

106. Malaysian's business process outsourcing sector. Journal of Sustainable Development, 9(2), 78 .

107. Qureshi, M.I., Iftikhar, M., Abbas, S.G., Hassan, U., Khan, K. and Zaman, K. (2013). Relationship between

108. job stress, workload, environment and employees' turnover intentions: What we know, what should we know. World Applied Sciences Journal, 23(6), pp.764-770

109. Ramlall, S. (2004). A review of employee motivation theories and their implications for employee retention

110. within organizations. The Journal of American Academy of Business, Cambridge, 5(1/2), 52-63

111. Richman, A.L., Civian, J.T., Shannon, L.L., Jeffrey Hill, E. and Brennan, R.T., 2008. The relationship of

112. perceived flexibility, supportive work-life policies, and use of forma flexible arrangements and occasional flexibility to employee engagement and expected retention. Community, work and family, 11(2), pp.183-197.

113. Rhoades, L. and Eisenberger, R. (2002). Perceived organizationa support: A review of the literature. Journal

114. of Applied Psychology, 87(4), 698-714.

115. Saunders, M., Lewis, P., \& Thornhill, A. (2012). Research Methods for Business Students. Essex: Pearson

116. Schutte, N. S., \& Loi, N. M. (2014). Connections between emotional intelligence and workplace flourishing.

117. Personality and Individual Differences, 66, 134-139.

118. Sekaran, U. and Bougie, R. (2016). Research Methods for Business: A Skill-Building Approach.

119. 5th ed., Chichester: Wiley

120. Smollan, R.K., \& Sayers, J.G. (2009). Organizational culture, organizational change and emotions: A qualitative study. Journal of Change Management, 9(4), 435-457.

121. Sarstedt, M., Christian M. Ringle, D. S. \& Reams, R. (2014). Partial leas squares structural equation

122. modeling (PLS-SEM): A useful tool for family business researchers. Journal of Family Business Strategy, 5(1), 105-115.

123. Stanley, R. O. \& Burrows, G. D. (2001). Varieties and functions of human emotion. In R. L. Payne \& C. L.

124. Cooper (Eds.). Emotions at work: Theory, research and applications in management. (pp. 3-19). Chichester, England: Wiley

125. StarOnline, (2018). Vacancies in banking industry, 16 January [Online] Available at

126. https://www.thestar.com.my/business/business-news [Accessed July 4, 2018].

127. StarOnline, (2014). Tighter squeeze on-talent increase in-gen y workforce in financial services, 6 January

128. [Online]. Available at https://www.thestar.com.my/business/business [Accessed July 4, 2018].

129. Strauss, W., \& Howe, N. (1991). Generations: The History of America's Future 1584 to 2069 . New York, NY:

130. William Morrow and Company.

131. Taris TW, Schreurs PJ. (2009). Explaining worker strain and learning: how important are emotional job

132. demands? Anxiety Stress Coping. 22(3), 245-62

133. Tower Watson, (2013). Higher turnover rate in Malaysian financial services industry, Towers Watson

134. (Online) Available at https://www.towerswatson, (Accessed June 18 , 2018

135. Tubre, T. C., \& Collins, J. M. (2000). Jackson and Schuler (1985) Revisited: A meta-analysis of the

136. relationships between role ambiguity, role conflict and job performance. Journal of Management, 26, 155-169.

137. Thibaut, J.W. \& Kelley, H.H. (1959). The Social Psychology of Groups. New York: John Wiley and

138. Sons,

139. Van Vegchel N, de Jonge J, Söderfeldt M, Dormann C, Schaufeli W (2004). Quantitative Versus

140. Emotional Demands Among Swedish Human Service Employees: Moderating Effects of Job Control and Social Support. International Journal of Stress Management. 11(1), 21-40.

141. Wilson, C. (2012). Retaining good people through a focus on talent and purpose. Human Resource

142. Management International Digest, 20(2), 29-31.

143. Wong, C. S. and Law, K. S. (2002). The effects of leader and follower emotional intelligence on

144. performance and attitude: An exploratory study. Leadership Quarterly, $13,243-274$

145. Woolfolk, A. (2004). Educational Psychology, 9th edn., Allyn \& Bacon, Boston, MA

146. Worley JA, Vassar M, Wheeler DL, Barnes LLB. (2008). Factor Structure of Scores from the Maslach

147. Burnout Inventory: A Review and Meta-Analysis of 45 Exploratory and Confirmatory Factor-Analytic Studies. Educational and Psychologica Measurement. 68(5), 797-823

148. World Health Organization (2008). The global burden of disease: 2004 update. Switzerland: WHO Press;

149. Zeidner, M., Matthews, G., and Roberts, R. D. (2009). What We Know About Emotional Intelligence:

150. How It Affects Learning, Work, Relationships, and Our Mental Health Cambridge, MA: MIT Pres

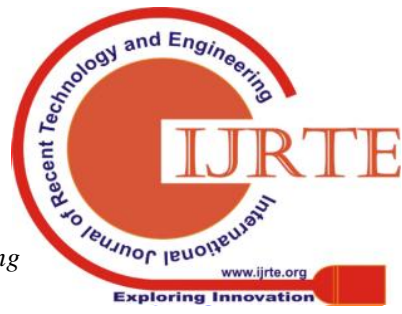

